\title{
ORGANIC REVELATION IN THE THEOLOGY OF HERMAN BAVINCK
}

\author{
Rudy Phen \\ Gereja Reformed Injili Indonesia, Kemayoran \\ Korespondensi: rudyphen@gmail.com
}

\begin{abstract}
The reality of the Trinity compels Bavinck to view the revelation as one single historical and organic whole, a mighty worldcontrolling and world-renewing system of testimonies and acts of God. Organism is the appropriate apparatus to describe the unity-in-diversity of the external (ad extra) work of the triune God and it serves as an agent of unity in Bavinck's theology. He has formulated a unified and organic Reformed doctrine of revelation that is founded on his Trinitarian vision and has presented it as the key concept of Christian worldview.
\end{abstract}

KEYWORDS: Trinity; Herman Bavinck; revelation; organic; unity-indiversity; worldview; ad intra; ad extra.

ABSTRAK: Kesadaran akan realita Tritunggal mengharuskan Bavinck untuk melihat pewahyuan sebagai satu kesatuan yang historis dan organik, suatu sistem pernyataan dan tindakan Allah yang mengendalikan and memperbarui dunia. Organisme adalah alat yang tepat untuk menggambarkan kesatuan-dalam-keragaman pekerjaan eksternal (ad extra) dari Allah Tritunggal dan berfungsi sebagai agen kesatuan dalam teologi Bavinck. Ia telah merumuskan doktrin pewahyuan Reformed yang terpadu dan organik yang didasarkan pada visi Trinitasnya dan telah mempresentasikannya sebagai konsep kunci pandangan dunia Kristen.

KATA KUNCI: Trinitas; Herman Bavinck; pewahyuan; organik; worldview; kesatuan-dalam-keragaman; ad intra; ad extra. 


\section{Introduction}

The concept of divine revelation is considered one of the most fundamental of all theological questions. It is thought to be the foundation of religion and the source of the knowledge of God (theology). The reason is because religion presupposes and demands three things, namely the existence of God, the self-revelation of God, and the knowability of God. ${ }^{1}$ Revelation and religion stand or fall together. However, when it comes to the understanding of the concept and essence of divine revelation, there is immense confusion and there is no unified opinion. This study is an attempt to outline the concept of revelation in the theology of a Dutch Neo-Calvinist theologian, Herman Bavinck. Among his works, the doctrine of revelation occupies a prominent place in his theology. It is arguably a common theme he lectured and wrote in various significant opportunities during his career life. When he was invited to deliver the Stone lecture (1908-1909) at Princeton Theological Seminary, revelation was again his topic of choice, entitled The Philosophy of Revelation. Therefore, it is not unwarranted to say that revelation is clearly among Bavinck's leitmotifs.

\section{Trinity as a Theological Centerpiece}

\section{The Trinitarian Worldview}

Bavinck was arguably considered as a worldview theologian that is richly rooted in Trinitarian, Reformed doctrine of God. ${ }^{2}$ The acknowledgment of God as triune becomes the literal centerpiece of Bavinck's theology is not unwarranted, as it can be observed from his tantalizing statement,

The thinking mind situates the doctrine of the Trinity squarely amid the full-orbed life of nature and humanity... The Christian mind remains unsatisfied until all of existence is referred back to the triune God, and

\footnotetext{
1 Herman Bavinck, Reformed Dogmatics, vol. 1: Prolegomena, ed. John Bolt, trans. John Vriend (Grand Rapids: Baker Academic, 2003), 505.

2 James Eglinton, Trinity and Organism: Towards a New Reading of Herman Bavinck's Organic Motif (London: Bloomsbury T\&T Clark, 2012), 82, 128.
} 
until the confession of God's Trinity functions at the center of our thought and life. ${ }^{3}$

Barth appreciates Bavinck's presentation of the Trinity as one of the most careful and instructive that he knows. ${ }^{4}$ Bristley provided helpful summary of Bavinck's contribution to theology. In his observation, he stated that one of the strength in Bavinck's theology is his profound understanding of the doctrine of Trinity. The doctrine of Trinity, for Bavinck, was not only the very heart of Christian faith but also has a profound implication. He further stated that Bavinck developed what may be termed a "Trinitarian methodology." 5 Vanhoozer, in his analyses of the very idea of a Trinitarian system, commented that Bavinck made the Trinity into a worldview. ${ }^{6}$

The last observation to show the prominence of Trinity in Bavinck's theology is in his intentional ordering of his dogmatics along a triniform contour. For Bavinck, all theology is the doctrine of God. The doctrine of God is the sum total of theology. ${ }^{7}$ After laying the epistemological foundations in Prolegomena, Bavinck subsumed his dogmatics under three doctrines, namely, of the Father (God and Creation), of the Son (Sin and Salvation in Christ), and of the Holy Spirit (Holy Spirit, Church, and New Creation). By ordering his dogmatics in a triniform structure, Bavinck retold "the story of God via the Father's divine creativity, the Son's work of redemption and the Spirit's glory in consummation." ${ }^{8}$ If

\footnotetext{
3 Herman Bavinck, Reformed Dogmatics, vol. 2: God and Creation, ed. John Bolt, trans. John Vriend (Grand Rapids: Baker Academic, 2004), 330. John Bolt commented "Put more simply, the fundamental theme that shapes Bavinck's entire theology is the Trinitarian idea that grace restores nature." ("Editorial's Introduction", $R D, 2: 18$ ).

4 Karl Barth, The Gottingen Dogmatics: Instruction in the Christian Religion, Vol 1, ed. Hanelote Reiffen, trans. Geoffrey W. Bromiley (Grand Rapids: Eerdmans, 1991), 97.

5 Eric Bristley, Guide to the Writings of Herman Bavinck (Grand Rapids: Reformation Heritage Books, 2008), 21-2.

6 Kevin J. Vanhoozer, "Three (or More) Ways of Triangulating Theology: On the Very Idea of a Trinitarian System," in Revisioning, Renewing, Rediscovering the Triune Center: Essays in Honor of Stanley J. Grenz, ed. Derek J. Tidball, Brian S. Harris, Jason S. Sexton (Eugene: Cascade Books, 2014), 38.

7 Eglinton, Trinity and Organism, 95.

8 Ibid., 93.
} 
God is truly triune, then it has to be supremely important because all things are from him, and through him and to him, as articulated by Bavinck that

The entire Christian belief system, all of special revelation, stands or falls with the confession of God's Trinity. It is the core of the Christian faith, the root of all its dogmas, the basic content of the new covenant. In the doctrine of Trinity we feel the heartbeat of God's entire revelation for the redemption of humanity. ${ }^{9}$

In his explication of the influence of doctrine of God to Bavinck's worldview, Eglinton observed that in examining Reformed Dogmatics

its content reads like a running battle between Trinitarian and nonTrinitarian theologies of God... Clearly, God's triunity exerts more than a schematic influence on Reformed Dogmatics. Micro- and macrocosmically, Bavinck's constant concern is the Trinity. ${ }^{10}$

Having briefly discussed the place of the doctrine of Trinity in Bavinck's thought, it will continue to explore the elements of the Trinity that substantially influence Bavinck's theology. It will discuss, firstly, the theme of unity-in-diversity; and secondly, Bavinck's view that Trinitarian ad intra leads to divine works ad extra.

\section{Unity-in-Diversity}

Bavinck views that the truly living God necessitates the triune God. The Trinity shows to us that God is essentially distinct from the world (creation) and having a blessed life of his own. ${ }^{11}$ He is independent, selfsufficient, and the eternal One, who is and was and is to come. He has fullness of life in himself. Particularly important in the theology of Bavinck is the understanding that the Trinity also reveals to us that there is unity in diversity, since in the Trinity the one selfsame being sustained by three persons. In the divine being there is unity in substance (essence)

\footnotetext{
RD, 2:333.

10 Eglinton, Trinity and Organism, 101.

11 RD, 2:331.
} 
and diversity in persons. Furthermore, for Bavinck, in God's being both, absolute unity as well as absolute diversity, are present. ${ }^{12}$ This absolute unity and diversity in the divine being results in the most perfect kind of community, a community of the same beings, and at the same time it results in the most perfect diversity, a diversity of divine persons. ${ }^{13}$ Bavinck concluded that if God is triune then the unity of the three persons can only be conceived as being consubstantial. The distinction must be in the same essence because in God there cannot be anything that is something other or less than God and there is nothing intermediate or transitional between the Creator and the creature. Therefore, either Father, Son and Spirit all possess the same being and are truly God or else they sink to the level of creatures. ${ }^{14}$ Eglinton observed, from the structure of Reformed Dogmatics Vol. 2 - God and Creation, that the theme of divine unity-in-diversity is at the heart of it. ${ }^{15}$ He concluded that the most rudimentary characterization of God, for Bavinck, is "as a being of immense diversity and profound unity."16

\section{Trinitarian Ad Intra Leads to Divine Works Ad Extra}

Bavinck's worldview that was profoundly rooted in his Trinitarian theology can also be observed from his view of the correlation between the Trinity ad intra and the divine works ad extra. What happens in the life of Trinity profoundly shapes the external reality outside the Trinity. Bavinck tied all the works ad extra to the Trinity ad intra. He asserted that, "These immanent relations of the three persons in the divine being also manifest themselves outwardly (ad extra) in their revelations and works." 17 The inner life of the Trinity is crucial for Bavinck. The Trinity reveals God with rich inner life. This life is fecund and it implies

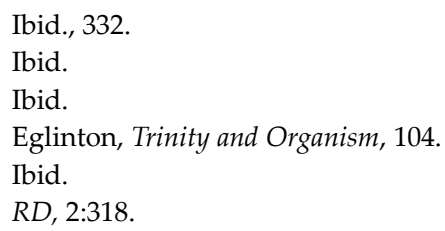


communication, action and productivity. Bavinck argued that

if the divine being were not productive and could not communicate himself inwardly (ad intra), then neither could there be any revelation of God ad extra, that is, any communication of God in and to his creatures..$^{18}$

The linking of the Trinity ad intra to the divine works ad extra can be clearly observed in Bavinck's discussion of creation and providence. The way he structured the part III of God and Creation in Reformed Dogmatics follows this line of thought. He starts with "The Divine Counsel"19 which represents the Trinity ad intra and then follow with "Creation" 20 which represents the divine works ad extra. The doctrine of the Trinity is of the greatest importance for the doctrine of creation since, for Bavinck, the self-communication that takes place within the divine being is archetypal for God's work in creation. ${ }^{21}$ Therefore, Bavinck stated, "if God were not triune, creation would not be possible." 22 Eglinton, in exploring the hypothesis that Bavinck's theology of Creator as Trinity necessitates the conceptualization of creation as organism, believes that the exploration of how Bavinck's view of the Creator, which affected his view of the creation, is a wider exploration of Bavinck's statement of the place of prominence and centeredness of the Trinity in the thought and life of the Christian. ${ }^{23}$

Of the particular interest when mining Bavinck's work on this is that one will find Bavinck regularly brought up the theme of unity-indiversity in the work of creation. Unity-in-diversity ad intra in Trinity leads to unity-in-diversity ad extra in creation. Bavinck emphasized on the unity of the divine works while preserving the diversity. He viewed that all divine works ad extra, such as creation, providence, rule, incarnation, satisfaction (atonement), renewal, sanctification, and so on, are the works

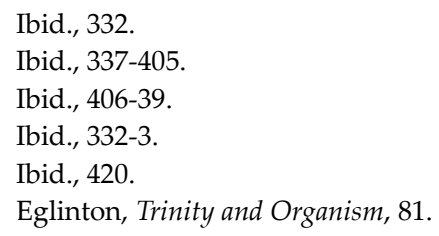


of the Trinity as a whole. ${ }^{24}$ The oneness of God guarantee the perfection of a creature, the completeness of a system, the harmony of beauty. ${ }^{25}$ However, this unity should not be over emphasize to the point of lacking diversity since each person in the Trinity has its distinct relation to the divine works. Finally, Eglinton asserted that the unity-in-diversity, as the most rudimentary characterization of God for Bavinck, exerts a controlling influence on Bavinck's understanding and appropriation of all created reality. ${ }^{26}$ As such, Eglinton concluded that "at the core of Bavinck's methodology is the principle that an essential coherence exists between Creator and creation." 27 A coherence where the cosmos bear the inevitable marks (vestiges) of its Triune Creator. For Bavinck, the inevitable marks of Trinity (vestigia trinitatis) primarily locates in the paradigm of unity-in-diversity on the basis of the archetypal unity-indiversity of the Triune Creator. ${ }^{28}$

\section{The Organic Motif}

In the past, Bavinck's scholarship has been marked by what normally called as "two Bavincks" model, which has operated on the premise, while arguing that Bavinck adopted the definition of organic motif from German Idealism and the Ethical Theologians, that his thought is inherently in conflict and contains many irreconcilable themes in tension with one belongs to 'Reformed Orthodox Bavinck' and another belongs to 'Modernist Bavinck'. Scholars have used "two Bavincks" hermeneutics to mining the mind of this great theologian. ${ }^{29}$ This hermeneutics has provided a lens through which Bavinck has been interpreted and consequently producing a division of Bavinck's work without a

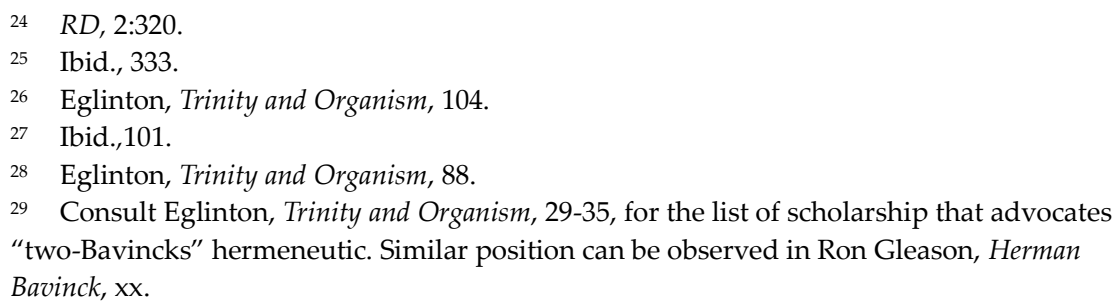


coherence unity. The "two Bavincks" hermeneutics also implied the view that Bavinck never reconciled the basic duality of orthodoxy and modernity and see it as impossible task to reconcile this tension. Consequently, Bolt saw that different people could use Bavinck as authority to support their views and agendas. ${ }^{30}$ The more recent work which perhaps represent the apex of this annexation is the work of Van Drunen, wherein he asserts that the reality of the "two Bavincks" model requires Bavinck to be read with segregationist hermeneutics. "Though a complete account is more complex, a good general argument can be made", he writes, "I believe, that his defense of the natural law and two kingdoms categories belongs to the orthodox Bavinck and his advocacy of themes such as grace restoring nature and the kingdom as leaven belongs to the modern Bavinck." 31

Recently, however, two monographs have refuted the "two Bavincks" interpretation and the assertion that Bavinck adopted his organic motif from German Idealism and Ethical theologians. ${ }^{32}$ Mattson argued that "Bavinck saw no such dichotomy" and "there is only one Bavinck: the one who sought to articulate a scriptural theology in the context of, and with recourse to the categories of, Reformed orthodoxy." 33 He argued that Bavinck deploys the organic motif for the purposes of persuasion by redefining that motif with internal sources from classical Reformed tradition. ${ }^{34}$ Therefore, one should not operate on the assumption that the tension Bavinck felt between his confessional commitment and his attraction to modernism was an unresolved tension.

\footnotetext{
30 John Bolt, "Grand Rapids Between Kampen and Amsterdam: Herman Bavinck's Reception and Influence in North America", Calvin Theological Journal 38 (2003): 265. He quoted G. C. Berkouwer, Zoeken en Vinden: Herinneringen en Ervaringen (Kampen: Kok, 1989), 55; "because Bavinck's theology contains so many irreconcilable themes in tension."

31 David Van Drunen, "The Kingship of Christ is Twofold: Natural Law and the Two Kingdoms in the thought of Herman Bavinck", Calvin Theological Journal 45 (2010): 162, footnote 75 .

32 Brian G. Mattson, Restored to Our Destiny: Eschatology and the Image of God in Herman Bavinck's Reformed Dogmatics (Leiden: Brill, 2012); James Eglinton, Trinity and Organism: Toward a New Reading of Herman Bavinck's Organic Motif (London: T\&T Clark, 2012).

33 Mattson, Restored to Our Destiny, 18.

34 Ibid., 54.
} 
Against the formerly normative "two Bavincks" hermeneutic, Eglinton has demonstrated the crucial flaws of this argument and argued that Bavinck's basic identity and concerns were primarily tied to the thoroughgoing Trinitarianism of historic Reformed orthodoxy. Therefore, he also departed from Berkouwer's claim that the organic idea was primarily, for Bavinck, a pragmatic choice and had no principled foundation in theology. It was simply a useful image that Bavinck saw fit to use. ${ }^{35}$

Having rejecting the "two Bavincks" hermeneutic and the claim that Bavinck adopted the definition of organic motif from German Idealism and the Ethical Theology, Eglinton explores the hypothesis that Bavinck's theology of Creator as Trinity necessitates the conceptualization of creation as organism: "Trinity ad intra leads to organism ad extra." ${ }^{36}$ In order to understand Bavinck's usage of the organic motif, instead of drawing its meaning from the original etymology or generic historical usage, one should deduce its meaning from Bavinck himself in his immediate context. Eglinton offers a summary of the definition of the organic motif in Bavinck's usage, as deduced from Bavinck's Christelijke Wereldbeschouwing. ${ }^{37}$ First, because God is Triune, the creation is marked by unity and diversity as an organic whole. Second, unity precedes diversity. It is orderly. God creates singular cosmos and he then fills it with diversity. Third, the organism is orchestrated by a common idea. it is unlike the chaos of multiformity. Fourth, the organism has its telos: the glory of the Triune God. The Trinity is glorified as the organism maintains simultaneous unity and diversity.

One observes, therefore, that Bavinck loads the meaning of organism with his concept of vestigia trinitatis. Instead of drawing its meaning from Idealist philosophy and Ethical theology, he binds his

\footnotetext{
35 G. C. Berkouwer, Zoeken en Vinden: Herinneringen en Ervaringen (Kampen: Kok, 1989), 62. as referred by Eglinton in Trinity and Organism, 82.

36 Eglinton, Trinity and Organism, 81.

37 Herman Bavinck, Christelijke Wereldbeschouwing (Kampen: Kok, 1904), 50-68, as referred by Eglinton, Trinity and Organism, 67-9.
} 
organic motif to the vestiges of Triune God. Eglinton observed that whenever Bavinck finds these vestigia, his motif of choice is that of the organic. ${ }^{38}$

On the other hand, it follows from the doctrine of human creation in the image of God that this image extends to the whole person. While all creatures display vestiges of God, only a human being is the image of God... Man is the image of God because and insofar as he is truly human, and he is truly and essentially human because, and to the extent that, he is the image of God. Naturally just as the cosmos is an organism and reveals God's attributes more clearly in some that in other creatures, so also in man as an organism the image of God comes out more clearly in one part than another, more in the soul than in the body, more in the ethical virtues than in the physical powers. ${ }^{39}$

He concluded that the organic motif is Bavinck's preferred means to communicate creation's triune shape. ${ }^{40}$ Unity and diversity is the particular expression of the creation's triune shape as an organism, both in its parts and as a whole simply because an archetypal unity-indiversity in the Godhead implies that creation displays an ectypal unityin-diversity. Therefore, the organic motif is viewed as an agent of conceptual unity in Bavinck's theology. ${ }^{41}$

This conceptual apparatus allows Bavinck to preserve a worldview that includes a unity that does not imply uniformity, and a diversity that resists separation or analytic dissection; it was used to 'facilitate, rather than to remove the tension between distinct elements in a system. ${ }^{\prime 42}$

Therefore, the "two Bavincks" model with the notion of the irreconcilable tension in Bavinck's theology is no longer tenable. These insights on the Bavinck's usage of the organic motif demand a different hermeneutic for reading Bavinck. Rather than seeing the irreconcilable tension in Bavinck's theology, one is exhorted to explore the organic motif

\footnotetext{
Eglinton, Trinity and Organism, 82. $R D, 2: 555$.

40 James Eglinton, “Bavinck's Organic Motif: Questions Seeking Answers," Calvin Theological Journal 45 (2010): 66.

41 Eglinton, Trinity and Organism, 79.

42 Eglinton, "Bavinck's Organic Motif", 67.
} 
as means of synthesis and unification in Bavinck's thought, as someone who believes that "the imperative task of the dogmatician is to think God's thoughts after him and to trace their unity." 43

\section{Bavinck's Theological Epistemology}

One of the main epistemological questions is the relation between subject and object in the realm of knowledge. All life and all knowledge, for Bavinck, is based on a reciprocal correspondence between the knowing subject and the known object. The objective reality can be approached only from the vantage point of the subject. The 'thing in itself' is unknown and does not exist for us. ${ }^{44}$ Therefore, in Bavinck's epistemology, the reciprocal correspondence between subject and object is the only way to gain trustworthy knowledge. ${ }^{45}$ There is an organic connection and correspondence between the knowing subject (internal) and known object (external) precisely because the same Logos created both the reality outside of us and the laws of thought within us. ${ }^{46}$ Accordingly, a governing concern in his epistemology is to demonstrate the fundamental unity of knowledge. Knowledge is an unity precisely because God is the source of all knowing. Bavinck demonstrates this unity by way he sets out principium (fundamental principle). ${ }^{47}$

Bavinck retains, from Reformed Orthodoxy ${ }^{48}$, the distinction

\footnotetext{
$43 \quad R D, 1: 44$.

44 Ibid., 586. Bavinck gave an illustration that the world of sounds has reality only to those who hear and it is futile to prove the objective existence of colors to the blind. In $R D, 2: 70$, "that for us to see we need both the light of the sun (objectively) and our eyes (subjectively). That humans learn and obtain knowledge from their environment is a fact; but it assumes that they come equipped with an ability, an aptitude, and a disposition to learn."

45 Cf. $R D, 1: 214,246,501,586$.

46 Ibid., 231.

47 The term principium was generally understood as the ultimate cause of things, the origin, the source, foundation, fundamental principle. Cf. $R D, 1: 210-1$.

48 Pass observed that Bavinck's epistemology "represents a remarkable example of synthetic character of his theology as a whole" in a way that although he adopted Aristotelian framework, which inherited from Reformed Orthodoxy, he modifies this framework to accommodate a distinctly Trinitarian description of knowledge. Bruce Pass, "Herman Bavinck and the Problem of New Wine in Old Wineskins", IJST Vol. 17/4 (2015): 435 .
} 
between a principle of being (principium essendi) and a principle of knowing (principium cognoscendi). He, however, draws a further distinction, within his principium cognoscendi, between an external principle of knowing (principium cognoscendi externum) and an internal principle of knowing (principium cognoscendi internum). This distinction is rare in Reformed Orthodoxy ${ }^{49}$ and it plays a prominent structural role in rendering service to both Bavinck's theological and general epistemology. Instead of a binary structure, he formulated a ternary structure of principium that affords the possibility to formulate a Trinitarian theological epistemology in which God the Father as principium essendi, God the Son as principium cognoscendi externum, and God the Holy Spirit as principium cognoscendi internum. Bavinck writes

these three principia, distinct yet essentially one, are rooted in the Trinitarian being of God. It is the Father who, through the Son as Logos, imparts himself to his creatures in the Spirit. ${ }^{50}$

The ternary structure of Bavinck's principium, through the further distinction of principium cognoscendi into external and internal principle, provides a tool to deal with the subject-object dichotomy. ${ }^{51}$ It is formulated in such a way that it displays the work of triune God and grounds the organic connection between knowing subject and known object within the organic unity of the Divine essence. ${ }^{52}$

\section{Organic Revelation}

\section{What is Revelation?}

Although Bavinck argues the case for revelation and its inseparable correlation to religion, he acknowledges that there was an immense confusion and no unified opinion with regard to determining the essence

\footnotetext{
49 Henk Van den Belt, Autopistia: The Self-Convincing Authority of Scripture in Reformed Theology (Doctoral Thesis, Leiden University, 2006), 258.

$50 \quad R D, 1: 214$.

51 Van den Belt, Autopistia, 271.

52 Pass, "Herman Bavinck and the Problem of New Wine in Old Wineskins," 436.
} 
and concept of revelation. ${ }^{53}$ The reason for this confusion, in his observation, is due to the usage of relevant terminology while its substance is quite radically different among one another. At best, this proof that the concept of revelation is generally recognized even by many parties outside of the circle of Christian theology, it nevertheless fosters misunderstanding and confusion. ${ }^{54} \mathrm{He}$ asserts that "Revelation" certainly is not a series of sounds without content, not a neutral flag, which can cover all kinds of cargoes, but a word that conveys a specific concept." 55 Bavinck defines the term "revelation" with following general definition,

Revelation is the communication or announcement of something that is still unknown and in the domain of religion includes three elements: (1) The existence of a personal divine being who originates the announcement; (2) a truth, fact, or event that up until the time of its announcement was not yet known; (3) a human being to whom the announcement was made. ${ }^{56}$

By accepting this definition, naturalism, in the form of materialism and pantheism, has not right to speak of revelation. ${ }^{57}$ Even within Christian theology the matter is not straight forward. Bavinck judges the protestant theologian devoted to little attention to this concept and too quickly to equate revelation with the inspiration of Holy Scripture. ${ }^{58}$ To understand the true concept of revelation, Bavinck asserts, it can only be derived from revelation itself. "it [revelation] - and it alone - must furnish us the concept and indicate to us the criterion we have to apply in our

\footnotetext{
$53 \quad R D, 1: 295$.

54 Bavinck refers to the various thoughts both in the field of theology and philosophy. See $R D, 1: 287-98$.

55 Ibid., 295.

56 Ibid.

57 Bavinck charged that those who repudiates the confession of a personal, self-conscious God and yet speak of revelation of God, are giving a different meaning to the word. Manifestation is a more proper word for those point of views. See Herman Bavinck, Our Reasonable Faith: A Survey of Christian Doctrine, trans. Henry Zylstra (Grand Rapids: Eerdmans, 1956), 34.

$58 \quad R D, 1: 288$.
} 
study of religions and revelations."59

So what had Bavinck perceived that the revelation had furnished about itself? Bavinck elucidates his understanding of revelation as selfdisclosure of God. ${ }^{60}$ This self-disclosure, whether in general or special form, has three characteristics. Firstly, "It always come from God himself acting in his freedom." ${ }^{61}$ It upholds the absolute sovereignty of God who acts with perfect freedom and deliberation. Every idea of revelation always demand the acknowledgment of the existence of personal and self-conscious God. Without self-conscious and self-knowledge God, no knowledge of God is possible. Secondly, "every revelation which proceeds from God is self-revelation." 62 Not only is God the origin of his revelation, $\mathrm{He}$ is also its content. Veenhof, in articulating Bavinck's thought on revelation, stated that "though revelation entails communication, it has to be borne in mind that God does not primarily communicate a series of supernatural truths, but rather there is essentially revelation of himself, self-revelation." ${ }^{63}$ Not only in Christ, as the highest revelation, but also in all of his works that He reveals to us his attributes and incomprehensible and worshipful being. At this point, Bavinck maintains his commitment to the Creator-creature distinction. He emphasizes on the infinite self-knowledge or self-consciousness of God in himself. The self-revelation is not identical with God's selfknowledge. This knowledge of God, from his revelation, though limited and finite, is nevertheless a real and sound knowledge. ${ }^{64}$ Thirdly, "the revelation which proceeds from God, and which has God as its content, also has God as its purpose." ${ }^{65}$ God is the origin, the content and the goal

\footnotetext{
59 Ibid., 299.

60 Bavinck, Our Reasonable Faith, 34-36. The term 'self-revelation' or 'self-communication' is used in the Reformed Dogmatics Vol. 1 to convey the same idea. Cf. RD, 1:340.

61 Ibid., 34 .

62 Ibid., 35.

63 Jan Veenhof, "Revelation and Grace in Herman Bavinck" in The Kuyper Center Review, Vol. Two: Revelation and Common Grace, Ed. John Bowlin. (Grand Rapids: Eerdmans, 2011), 4 .

64 Bavinck, Our Reasonable Faith, 35

65 Ibid., 36.
} 
of his revelation. He is the alpha, the center and the omega. The highest purpose of revelation does not rest in man, i.e. in acquiring knowledge of God and that in believing they might have eternal life. Rather, its highest purpose is in God's glorification. This marks the Trinitarian shape of Bavinck's doctrine of revelation. As Eglinton observes, "this brings Bavinck's doctrine of revelation firmly into alignment with his broader worldview that all things begin and end with the glory of the Triune God." 66

As discussed earlier, ${ }^{67}$ the fecund inner life of the Trinity implies communication, action and productivity. The communicative attribute of the Trinity ad intra is the basis of the self-disclosure of Trinity ad extra. It provides apparatus for Bavinck to establish the connection between revelation and creation, incarnation and the outpouring of the Holy Spirit. If Bavinck's doctrine of revelation is grounded on the Trinity, one is set to explore the organic character of it. Eglinton asserted that the Trinitarian shape of Bavinck's doctrine of revelation inherently produces the organic character.

As such it would be hardly surprising if the basic character of the Trinity's self-revelation were developed along the lines of unity, diversity, relationship, linkage and interconnectivity. One would expect, therefore, that revelation would have an inherently organic character. ${ }^{68}$

\section{An Organic Revelation}

Organic motif is a conceptual apparatus which allows Bavinck to maintain the unity-in-diversity paradigm in his theology. ${ }^{69}$ It is viewed as an agent of conceptual unity in his theology. Therefore, one observes the organic character of Bavinck's doctrine of revelation. Firstly, he rejects the dualistic approach. Bavinck rejects the natural and supernatural distinction of revelation. For him, all revelation is supernatural. Secondly,

\footnotetext{
Eglinton, Trinity and Organism, 138.

Under the sub-heading of "Trinitarian ad intra leads to divine works ad extra"

Eglinton, Trinity and Organism, 138.

69 Under the sub-heading of "The Organic Motif".
} 
he crystallizes his organic thinking with the teleological character of revelation against the mechanical and anti-teleological conception. Thirdly, he maintains the unity and the interconnectedness in his system. $\mathrm{He}$ rejects the dichotomy of objective and subjective revelation. He, instead, formulates twofold structure of revelation consists of both objective (external) and subjective (internal) aspects and articulates its unity.

\section{Supernatural Revelation}

Bavinck observes that at the very early development, Christian theology had made distinction between natural and supernatural revelation. The church fathers have posited a contrast between the two revelations, equated special revelation with supernatural and contrasted it to the natural. ${ }^{70}$ The further development in Medieval Scholasticism made the distinction more rigorous and became an absolute contrast. Bavinck critiques this development as becoming inherently dualistic, particularly in the development of the medieval Roman Catholicism. Bavinck observed that the dualistic nature-grace motif in Roman Catholic theology produces the natural and supernatural categories. This dualistic system formulates two conceptions of human beings: their nature and destiny. ${ }^{71}$ This mere natural human, without the image of God and not effected by the fall, may acquire a pure knowledge of God. However, it pleases God to give human beings a higher, a supernatural and heavenly, destiny. In order to achieve this, God must bestow upon them a supernatural grace. In this dualistic worldview, there is a quantitative contrast between natural and supernatural. They are essentially two distinct systems and orders. Grace is elevated high above nature. Consequently, there are two conceptions of revelation, namely, natural and supernatural revelation. Supernatural revelation is a separate and higher order than natural revelation. It surpasses natural (created things)

$\begin{array}{ll}70 & R D, 1: 302,355 . \\ 71 & \text { Ibid., 358. }\end{array}$ 
and does not have its cause in creatures but in the omnipotence of God. Supernatural revelation is a "supernatural grace" bestowed upon natural human beings whom possessed the natural knowledge acquired from nature and reason (natural revelation). Bavinck argues the substantial dangers of this view is that the special revelation is detached from creation and nature. This can lead to understanding special revelation as separation, altogether stand by itself with no connection to nature and history. "In that case, its historical and organic character was denied."72 In Bavinck's view, the Reformation keeps the naturalsupernatural distinction but in principle assigning a very different meaning to it. They accepts a revelation of God in nature but because the human mind was so darken by sin, human beings could not rightly know and understand it. They also introduced changes in the way supernatural revelation is viewed. It is so-called supernatural revelation "primarily because it far exceeded the thoughts and wishes of sinful fallen human beings." 73 However, Bavinck concluded that even the Reformers did not always succeed in transcending the dichotomy between natural and supernatural revelation. ${ }^{74}$

Bavinck acknowledged the validity of the dual distinction. He concurred that the Scripture recognizes this duality, namely, "an ordinary order of nature" and "the deeds and works that are causally rooted in the omnipotence of God." 75 The reality of revelation in Scripture presupposes the existence of another, higher and better world than this nature. However, Bavinck objected the distinction between natural and supernatural revelation. He argued that "While the Scripture does know a distinction between the ordinary course of things and the extraordinary

\footnotetext{
72 Ibid.

73 Ibid., 305.

74 Ibid. Bavinck claims that because of the challenge from Anabaptism and Socialism, Luther was compelled to make sharp distinction between the spiritual and secular, heavenly and earthly. It was ultimately followed by Lutheran theologians in creating "two hemispheres", one of which was inferior and the other superior. Even Calvin, though in a more favorable position than Luther, still did not always succeed.

75 Ibid., 356.
} 
works of God, it does not posit a contrast between "the natural" and "the supernatural". ${ }^{76} \mathrm{He}$ makes exegetical point that Scripture uses the same terminology ( $g a-l a(h)$, apokaluptien, phaneroun) to describe for natural revelation as it is used for supernatural revelation. ${ }^{77}$ Bavinck's objection to the categorization of natural and supernatural revelation is also based on his observation that the so-called natural and supernatural revelation are intermingled. There is element of natural in supernatural revelation and vice versa. ${ }^{78}$ His objection was grounded on the belief that all revelations, included those that in nature, is inherently supernatural. ${ }^{79}$

There are few characteristics of Bavinck's conception of supernatural revelation. Firstly, as this revelation is a self-disclosure of God, it has its origin from God. ${ }^{80}$ Theism is inherently supernaturalistic because "it assumes a transcendent personal God and, by implication, recognizes a world beyond this world." 81 Secondly, supernatural revelation is not identical with immediate revelation. ${ }^{82}$ Bavinck argued that there is no immediate revelation in a strict sense, either in nature or in grace. God always uses a means in revealing himself. The motif of Creator-creature distinction necessitates that all revelation is mediate. The chasm between the Creator and creature is too great for human beings to be able to perceive God directly. "No creature can see or understand God as he is and as he speaks in himself." 83 Thirdly, It is God's act of grace. In Bavinck's view, revelation is "never an unconscious emanation, an involuntary translucency of God in his works, but always a free, intentional and active act of making himself known to human beings." 84 Therefore, it is always an act of God. Veenhof observed that

\footnotetext{
76 Ibid., 355.

77 Ibid., 307. He provides example from Job 12:22; 33:16; 36:10; Rom. 1:18, 19.

78 Ibid., 311.

79 Ibid., 307.

80 Ibid.

81 Ibid., 297.

82 Ibid., 309.

83 Ibid., 310.

84 Ibid., 297.
} 
this revelatory action of God is motivated by His love, which is rooted in the Trinity. ${ }^{85}$ Because no creature can see or understand God as he is and as he speaks in himself, revelation is, therefore, always an act of grace. In revelation, God condescends himself to meet his creature. Therefore, God's revelation is always incarnational. In His revelation in nature, ${ }^{86}$ his divine and eternal thoughts have been deposited in creatures in a creaturely way so that it can be understood by human (creaturely) thought process. Likewise, in supernatural revelation, God binds himself to space and time, adopts human language and speech, and make use of creaturely means. By viewing revelation in this way, as mentioned earlier, Bavinck established the connection between revelation, creation, and incarnation, which has its root in Trinity ad intra. Bavinck observed a remarkable fact that sin brings "no change in the fact of revelation itself" as God continues to reveal himself. ${ }^{87}$ In Bavinck's view, the supernatural revelation was not made necessary because of the fall. It exists not only after but even before the fall (the state of integrity). What impact that sin brought to revelation is the specific content of revelation, which is the soteriological character of the revelation.

Even in the state of integrity, there was a revelation of grace, for then also the love relation in which God placed himself to human beings was a demonstration of unrestrained goodness. Hence what sin made necessary was not revelation as such but the specific content of revelation, i.e., special grace, the revelation of God in Christ, the incarnation of God. ${ }^{88}$

Another important point in Bavinck's conception of supernatural revelation as God's act of grace is that his motif of 'grace restores nature' implies that supernatural revelation and nature (creation) are not opposed to each other. ${ }^{89}$

\footnotetext{
Veenhof, "Revelation and Grace in Herman Bavinck", 4.

$R D, 1: 310$. Bavinck still uses the term 'natural revelation'.

Ibid.

Ibid., 359.

Ibid., 362.
} 
Having rejected the categorization of natural-supernatural revelation, Bavinck prefers the twofold categorization of revelation in corresponding to his understanding of revelation as an act of grace. The twofold character of grace (common and special) is correlated to the twofold character of revelation (general and special). Veenhof observed that "the notion of the common grace and general revelation basically function as correlate, just like special grace and special revelation." 90 Therefore, instead of categorizing revelation as natural and supernatural, Bavinck adopted the general and special revelation category inline with Reformed tradition. He concluded that "the distinction between natural and supernatural revelation is not identical with the distinction between general and special revelation."91

\section{Teleological Character of Revelation}

The second character, which profoundly marks Bavinck's organic revelation, is the teleological character of revelation. In Bavinck's view, revelation is not just as a number of disconnected words and isolated facts but as one single historical and organic whole. It is a worldcontrolling and world-renewing system of testimonies and acts of God..$^{92}$ It implies a teleological notion of the system. Dosker noted the close connection between the organic motif and the teleological character in Bavinck's conception,

Doctor Bavinck strenuously upholds the central and organic conception of revelation. It occupies a definitely teleological position; it reveals to us the coming of God to humanity, forever to dwell with humankind. ${ }^{93}$

The highest goal of God's self-revelation is that the rational creature knows God in order to glorify Him. In his writing on special

\footnotetext{
90 Veenhof, "Revelation and Grace in Herman Bavinck," 7.

$91 \quad R D, 1: 311$.

92 Ibid., 340.

93 Henry Elias Dosker, "Herman Bavinck" in Herman Bavinck, Essays on Religion, Science and Society, ed. John Bolt, trans. Harry Boonstra and Gerrit Sheeres (Grand Rapids: Baker Academic, 2008), 23.
} 
revelation, Bavinck stated that special revelation is not an end in itself. Even incarnation is the means toward a greater end. The purpose of revelation is not Christ, Christ is the center and the means. ${ }^{94}$ Scripture too is by its nature provisional, temporary and incidental. It is a means and an instrument, not a goal. ${ }^{95}$ The purpose is that God will again dwell in his creatures and reveals his glory in the cosmos. Hence, the purpose of special revelation ends in God himself. Bavinck applies his 'grace restores nature' motif in this case.

precisely in order to reach this final goal, the glorification of God's name, special revelation must strive to the end of re-creating the whole person after God's image and likeness and thus to transform that person into a mirror of God's attribute and perfections. ${ }^{96}$

The restoration of human being is at the center of the telos of special revelation. This revelation, taken as a whole, will have reached its telos only in the parousia of Christ. ${ }^{97}$

\section{Twofold Structure of Revelation}

For Bavinck, God's self-consciousness is the source of all knowledge. It is triune and interpersonal, and it implies communication ad intra. This communicative character secures the possibility of revelation. Therefore, God self-consciousness is the source (principium essendi), the primary efficient cause of our knowledge of Him..$^{88}$ Since the means by which we acquire the knowledge of God is God's revelation, therefore, the principle of knowing (principium cognoscendi) is God's self-revelation. Distinction was made between God's knowledge of himself and our knowledge of God. The reason that God is the principium essendi precisely because only God knows himself fully while our knowledge of God is "the imprint of the knowledge God has of himself but always on a creaturely level and in

\footnotetext{
$R D, 1: 380$.

Ibid., $213,380$.

Ibid., 346.

Ibid., 382.

Ibid., 212.
} 
a creaturely way." 99 The former is called archetypal knowledge of God and the latter is called ectypal knowledge of God.

Bavinck views that all knowledge is based on a reciprocal correspondence between the knowing subject (internal) and the known object (external). ${ }^{100}$ There is an internal organ of perception within human beings that corresponds to the external reality. ${ }^{101}$ Therefore, in his epistemology, this reciprocal correspondence between subject and object is the only way to gain certainty and unity of knowledge. Consequently, in acquiring the knowledge of God, the reciprocal correspondence between objective (external) and subjective (internal) revelation is necessary. ${ }^{102}$ Revelation must be received (internal) as well as given (external). ${ }^{103}$

The necessity of the objective-subjective revelation also ties to the teleological character of the revelation in Bavinck's theology. Precisely because the telos of God's self-revelation is "to introduce his knowledge into the human consciousness and through it again to set the stage for the glorification of God himself"104 hence revelation cannot stop at outside of human beings but must penetrate into inside, human consciousness.

Religion exists because God is God and want to be served as God by his rational creatures. To that end he reveals himself to human beings in word and deed (the external principle of knowledge) and makes them subjectively fit to know and love God by that revelation (the internal principle of knowledge). ${ }^{105}$

\footnotetext{
99 Ibid.

100 Hielema described this character of revelation in the context of relationship that it is given and received. "Revelation assumes, demands, and even creates and sustains the relational context within which it is given and is to be received." See Syd Hielema, Herman Bavinck's Eschatological Understanding of Revelation (Th.D. diss., Wycliffe College, Toronto School of Theology, 1998), 41.

101 RD, 1:279.

102 Ibid., 321. Bavinck observed that this idea had existed in the Reformers. Cf. RD, 1:304.

103 Ibid., 497.

104 Ibid., 213.

105 Ibid., 279.
} 
Therefore, objective (external) revelation demands a subjective (internal) revelation in the subject. The teleological character of the revelation also help Bavinck to see the necessity of the continual activity of the Holy Spirit after Christ-event, that the special revelation in Christ is not meant to be restricted to Christ himself but proceeding from Him and to be realized in the church, in humanity and in the world. For this reason, Bavinck noted on the insufficiency of the objective revelation in Christ and the necessity of the work of the Holy Spirit. He stated that

the objective revelation in Christ is not sufficient, but there needs to be added a working of the Spirit in order that human beings [the subject] may acknowledge and accept that revelation of God and thereby become the image of the Son. ${ }^{106}$

With these reasons, Bavinck further distinguishes principium cognoscendi (God's self-revelation) as external principle of knowing (principium cognoscendi externum) and the illumination of God's Spirit in human consciousness as internal principle of knowing (principium cognoscendi internum). One, particularly, has to understand the relationship between the Logos and the Holy Spirit in order not to misunderstand Bavinck's principium and render him any inconsistencies in his thought. For Bavinck, the Father works through the Son and in the Spirit. In creation, "there the Logos is, there the Spirit is also" and therefore the Father creates all things through the Word and in the Spirit. ${ }^{107}$ In the principle of knowing, God alone who conveys the knowledge of truth to our mind in the way that "the Father who by the Son and in the Spirit reveals himself to us." 108 Close to the end of his prolegomena, he asserted that

Construed religiously, it is the Logos himself who through our spirit bears witness to the Logos in the world. It is the one selfsame Spirit who objectively displays the truth to us and subjectively elevates it into

\footnotetext{
106 Ibid., 348.

107 RD, 2:421.

108 RD, 1:233.
} 
certainty in our spirit... All cognition of truth is essentially a witness that the human spirit bears to it and at bottom a witness of the Spirit of God to the Word, by whom all things are made. ${ }^{109}$

Here, Bavinck ties closely the work of the Logos and of the Spirit. It is the work of the Logos through the Spirit. As observed by Pass that "What Bavinck says about the Logos stands in epexegetical to the Holy Spirit's role of displaying the truth and elevating it into certainty in the knowing subject."110 Therefore, the Logos bears witness by the operation of the Holy Spirit and accordingly Bavinck does not hesitate to apply illumination as the work of the Logos. ${ }^{111}$

The objective (external) revelation, in Bavinck's view, took the form of word-act. ${ }^{112}$ God's word and his act are not to be separated. For Bavinck, "God's word is an act and his activity is speech. God not only reveals himself by his words but also by his works. Word and deed are intimately connected. Word and deed accompany each other." 113 In creation (nature) and providence (history), in the economy of Christ and in the economy of the Holy Spirit, God's word and his act go hand in hand. This objective revelation comprises general and special revelation, which includes the inspiration of the Scripture.

The subjective revelation, as the activity of the Holy Spirit, focuses on the consciousness and being of the person. This revelation consists in the illumination of the mind and the renewal of the heart. ${ }^{114}$ Due to his concern that the emphasizing of the subjective (internal) revelation may leads to subjectivism and independency, Bavinck ties the dependency of subjective to objective revelation closely.

\footnotetext{
109 Ibid., 587.

110 Pass, "Herman Bavinck and the Problem of New Wine in Old Wineskins," 445.

$111 R D, 1: 318$. "Also among pagans, says Scripture, there is a revelation of God, an illumination by the Logos, a working of God's Spirit." The Logos illumined by the personal agency of the Spirit.

112 The term 'act' and 'deed' are referred to the same meaning. In this writing, the term 'act' is used.

$113 R D, 1: 336$.

114 Ibid., 349.
} 
It [subjective revelation] can come into its own only if it is positioned in relation to the objective revelation granted in Christ. Detached from or elevated above this revelation, it loses its criterion and corrective and opens the door to all sorts of arbitrariness and fanaticism. Even the very concept of subjective revelation is determined and controlled by that of objective revelation.... but it [subjective revelation] is not a revelation in the sense that it adds a new element to objective revelation. Subjective revelation serves only to make this objective revelation known and have it appropriated by the believer. ${ }^{115}$

In his study of the Autopistia of Scripture in the theology of Bavinck, Belt concluded that "the Autopistia of Scripture counterbalances the subjectivistic tendency in Bavinck's theology."116

Bavinck reformulated the binary structure of principia, adopted from Reformed Orthodoxy, into the ternary structure and producing a Trinitarian theological epistemology in which God the Father as principium essendi, God the Son as principium cognoscendi externum, and God the Holy Spirit as principium cognoscendi internum. This provides a structure fit for his formulation of objective-subjective revelation. Concerning the natural knowledge of God (general revelation), 117 because God self-consciousness is the source of all knowledge, God is the principium essendi. The cosmos (creation) functions as principium cognoscendi externum, where the cosmos is the general revelation of God. Reason and conscience function as principium cognoscendi internum. The nature and history are the external objective means God employs to reveal himself while reason and conscience are the internal subjective means. 118 Concerning the redemptive knowledge of God (special revelation), God (the Father) functions as principium essendi. The revelation of God in Christ (the Son), and accordingly in Scripture, functions as principium cognoscendi externum. The illumination of the Holy Spirit functions as principium cognoscendi internum. These three principia,

\footnotetext{
115 Ibid., 348.

116 Henk van den Belt, Autopistia, 311.

117 The term of 'natural knowledge of God' does not imply natural revelation but knowledge of God which is acquired from nature (creation).

$118 R D, 1: 341$.
} 
although distinct, yet essentially one. God can be known only through God.

\section{Conclusion}

Bavinck's doctrine of revelation is profoundly shaped by his Trinitarian worldview. Revelation is self-disclosure of the Triune God. The communicative attribute of the Trinity ad intra is the basis of the selfdisclosure of Trinity ad extra. As it is grounded in his doctrine of Trinity, the organic character (unity-in-diversity) is pervasive in his doctrine of revelation. He strikes to build the coherence and unified system in his theological construction. He rejects any dualism approach which is fragmented or one-sided with opposing element. For him, revelation is one organic whole, progressing toward its goal in the glory of the Trinity. 